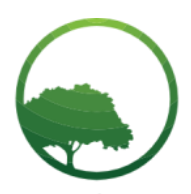

Research in Business \& Social Science

\title{
Relationship between stress management and job performance in organizations
}

\author{
Ozden Altindag(®)
}

Crossref

a, PhD. In Business Adminstration, Istanbul, Turkey

\begin{tabular}{l} 
A R T I C L E I N F O \\
\hline Article history: \\
Received 28 February 20 \\
Received in revised form 10 March 20 \\
Accepted 14 March 20 \\
\hline Keywords: \\
Stress, Stress Management, \\
Organizational Stress Management, \\
Job Performance \\
JEL Classification: \\
M10
\end{tabular}

\begin{abstract}
A B S T R A C T
This study aims to examine the concept of stress, which has become a part of our daily lives, in an organizational context, and to determine whether there are a relationship and interaction between stress management and job performance in organizations. In this article, which is an exploratory study, the sources behind organizational stress are investigated, and the individual and organizational results created by organizational stress management on business performance are discussed. Within the scope of the study, the studies in the literature conducted between 2005 and 2019 in different sectors and their results were examined. In the obtained results, significant negative relationships were found between stress management and job performance. Furthermore, in these results, the mediating role of stress management was also detected.
\end{abstract}

(C) 2020 by the authors. Licensee BSC International Publishing, Istanbul, Turkey. This article is an open access article distributed under the terms and conditions of the Creative Commons Attribution (CC BY) license (http://creativecommons.org/licenses/by/4.0/).

\section{Introduction}

As societies have tried to adapt to changes and developments experienced in the industry, technology, economy, social and cultural fields, the concept of stress has started to be involved in daily life. Stress factors have caused increasing pressure on individuals who fulfill their individual and professional responsibilities and try to gain a place to themselves in business life. Undoubtedly, one of the most significant input sources of businesses is human. It is possible that people will face individual, organizational, and environmental problems in working life.

In the age we live in, regardless of the job they do, individuals continue to live most of their lives by forcing their abilities and limits. While individuals are trying to keep up with dynamic and rapid changes in working experience, at the same time, they are trying to meet organizational needs. Various factors, such as relationships, interactions, behaviors, and the quality of management understanding, experienced in the internal and external environment of the organization can lead employees, who perform specific roles and tasks within the organization, to face organizational stress. Although organizational stress is a situation caused by employees' jobs and interaction with other individuals/groups, it forces them to differentiate from their normal functions. Due to stresses experienced in organizations, results such as the decrease in employee performance, the loss of motivation, slowing down the work, the decrease in productivity and creativity, leave of employment, and even the reduction in the performance of the organization can be observed. The main objectives of organizations are to sustain their lives, to grow, to develop, to increase their profits and productivity. These situations that are desired to be reached can be closely related to the improvement of employee performance by identifying the stress factors encountered by employees and reducing the negative consequences caused by stress. In relation to this scenario, answers to the following questions are sought; (i) Can organizational stress management affect and change the level of work performance in an organization? (ii) If it has an impact on business performance, does this have a negative impact on organizational processes? At the same time, this article aims to provide the literature for further research by compiling the results of the study on employees in different professions.

* Corresponding author. ORCID ID: 0000-0003-4341-6519

(C) 2020 by the authors. Hosting by SSBFNET. Peer review under responsibility of Center for Strategic Studies in Business and Finance. https://doi.org/10.20525/ijrbs.v9i2.636 
In summary, two significant findings were obtained as a result of this study. First; As a premise, stress factors have an overall significant and negative impact on business performance. Secondly, as the job performance of employees decreases, they are affected by organizational processes.

\section{Literature Review}

\section{Stress and organizational stress management}

Stress, which is considered to be one of the most critical problems of our age and affects the quality of life of living things, is the "war or runaway" reaction that an individual develops against a stimulus that threatens his/her adaptation to the environment (Civan et al., 2018: 2). While stress, which is a concept derived from the Latin word "estrictia," was used in the 17th century with the meanings of disaster, trouble, calamity, bother, and grief, in the 18th and 19th centuries, it was started to be used for psychological deteriorations in the individual, meaning "power, pressure, and stress" (Tekiner \& Tavas, 2016: 1658-1659). According to many researchers and scientists, stress, which is considered to be the social and psychological plague of today, is evaluated as a condition that occurs with the individuals being forced physically and mentally and feeling under pressure and tension (Armağan \& Kubak, 2013: 36).

The presence of individuals in working life can help them in gaining a regular job, physical and mental activity, social interaction, positive personal judgment, trust and competition, social prestige, purchasing power, and static social structure (Nart \& Batur, 2014: 72). According to Ergül (2012: 16-17), since the individual is affected by his/her relationships with the environment, individual differences, and psychological processes, these mental and physical desires of individuals may cause them to experience stress within the organization after a certain period of time. Organizational stress occurs due to the individual's reactions to the external environment, situations, or events. Likewise, Chen \& Silverthorne (2008: 573) defined job stress as psychological and physiological reactions caused by employees due to unfavorable conditions and circumstances in the workplace. According to Bilgili \& Tekin (2019: 2169), mostly, intense competition environment, changes in the social and economic structure, and technological developments can also cause stress, which is the outcome of modern life. The fact that individuals face stress at every moment of their lives adversely affects both their work and daily lives. Therefore, managing stress has become increasingly important for both employees and organizations. According to Mirela \& Mădălina-Adriana (2011: 1622 - 1623), who define organizational stress as emotional, cognitive, behavioral, and physiological reactions to harmful aspects of the job, work environment, and organizational climate, there are two types of organizational stress. (i) Eustress is positive stress, which improves the energy, creativity, and competitive spirit of individuals and which is used by individuals to achieve high performance. (ii) Distress is a type of stress that has adverse effects on individuals. It is observed in two forms as acute and chronic. Severe stress is negative stress that disrupts the creative thinking performance of individuals (Wang et al., 2019: 472). Chronic stress is non-specific systemic reactions, which occur with the prolonged exposure of the individual to various internal and external negative factors (Yao et al., 2019: 1429).

Studies on the sources of organizational stress list these sources under several headings. Among these, factors such as role conflict, role uncertainty, an inability to participate in decisions, not fully defined responsibility of the individual towards other employees, and the lack of a specific role of the individual in the organization are among the sources of organizational stress related to the individual's role in the organization (Gümüştekin \& Gültekin, 2009: 154). Excessive responsibility and risky jobs, high workload, monotonous, and unsatisfying work are the sources of organizational stress related to the nature of the work (Iş1k, 2007: 15-16). Over-centralization, difficulties experienced in participating in decisions, over-specialization, exposure to excessive workload, the lack of opportunities for progress and development, bureaucratic obstacles (the excess of procedures and rules) are among the sources of organizational stress related to the organizational structure (Altan, 2018: 144-147). Imbalances in the wage distribution, injustices in performance evaluation, few promotions and career opportunities, arbitrarily established policies, and too idealistic job descriptions are among the sources of organizational stress related to the organization's policies (Aydın \& Çavuş, 2017: 83). A high heat and humidity ratio, noise, under- or over-lighting, pollution, and insufficient ergonomic conditions are the sources of stress related to the physical conditions of the organization (Aydın, 2004: 8). Tekin (2010: 83-88) listed the stress management strategies of organizations, which want to control or minimize stress sources, under several methods. These are to create intra-organizational support and cooperation, to improve the content and quality of work, to identify organizational roles, to reduce conflicts, to plan career development paths, to create an equal remuneration system, to create a cheerful environment in the workplace, to perform the transfer of authority, and improve the working conditions. According to Özen (2013: 103), while organizational stress management aims to prevent and reduce mental and behavioral problems related to stress in individuals and organizations, it supports positive aspects of stress. For this, improving working conditions, redesigning the jobs, performing job enrichment, providing staff empowerment, organizing training programs, performing organizational time management, establishing social support systems, improving organizational climate, providing career planning and development, and enabling wage management is required.

\section{Job performance}

All attitudes and actions that are controlled by an employee in a workplace and which contribute to the achievement of the goals of the organization are called job performance (Demirer, 2019: 283). The concept of job performance, which defines to what extent the targeted job is performed, from an individual perspective, is the whole of the behaviors exhibited by the employee in order to contribute to the effort of the organization to reach its goals (Tekin \& Deniz, 2019: 71). At work, all behaviors that employees engage 
in are called job performance (Keskin \& Gündoğan, 2019: 1467). According to Baytaş (2018: 2), all activities related to the work performed by employees were defined as job performance. Performance is related to the quality of the way employees do the job. If employees do not have knowledge, skills, and competencies for the work they will do, stress on them increases, and while they lose their motivation, their performance may also decrease. According to Meydan et al. (2018: 78), job performance is a component of the task and contextual performance, and it is the efforts made by employees in order to achieve work-related objectives. Bin (2015: 2) defines job performance as the ability of an employee to achieve the objectives and organizational standards. According to Koca \& Yildiz (2018: 197), the concept of job performance is related to the existence of features (capacity) suitable for the requirements of the job, the employee's striving for his/her job (willingness), and the presence of environmental elements for the realization of the job. Job performance, which plays a vital role in realizing the goals and objectives of the organization, is realized at the same time by employees' demonstrating their capacity and willingness in accordance with their job descriptions and roles, and by receiving the support of the business environment.

According to Yardibi (2018: 427), increasing motivation, the existence of a rewarding system, the harmony between employee expectations and goals of the organization, effective communication, and trust, adequate and correct functioning of the performance evaluation system, the high level of employee satisfaction are directly related to job performance.

\section{Relationship between stress management and job performance in organizations}

The psychological structure of employees is directly reflected in the work they do and their work lives. Therefore, stressful employees mean that the organization is stressful. All kinds of problems caused by stress reflect in business relations and business success by affecting the performance of the individual directly. The studies, examining the relationship between stress and performance in organizations, have accepted the existence of four approaches (Gümüştekin \& Öztemiz, 2005: 282).

Negative Relationship: There is an inverse relationship between stress and performance, and it is assumed that performance will decrease as the stress level increases. According to this model, employees who want to reduce their stress can waste their time and do unwanted behaviors (Çargan, 2018: 36).

Positive Relationship: According to this model, job performance will increase as job stress increases. The challenges, concerns, and competitive environment in the workplace are opportunities for the employee to put forward constructive actions and improve his/her performance. High-level stress means high competitiveness, thus, high performance (Y1lmaz, 2006: 99-100).

Inverse U-Shaped Relationship: The relationship between stress and performance is inverse u-shaped and consists of a combination of positive and negative relationship models in general. While stress that increases until a certain level improves performance, the ability to work efficiently decreases rapidly if stress exceeds the critical level (Akgündüz, 2006: 64).

No Relationship: Although there is a psychological agreement between the employee and the organization, there is no relationship between stress and performance. According to this model, employees know that they will receive a certain wage for their performance. The presence or absence of stress does not affect performance (Türkmen, 2015: 46).

The stress level, at which individuals' performance is the best, is the optimal positive stress level. At the positive stress level, the individual's motivation, ability to fight time pressure, speed of making important decisions, and contribution to performance are faster and higher. In cases when individuals cannot cope with personal and environmental dangers, stress transforms into negative stress, and this increases the presence of individuals who need help, who experience difficulty in adapting to the environment, and who cannot transfer their energy to their work (Düğenci, 2018: 7). Since the psychological structures of individuals in the workplace are directly reflected in the work they do, stressful individuals mean that the whole organization is stressful. All kinds of discomfort, psychological and mental problems experienced due to stress are directly reflected in employee performance, business relations, and business success (Gümüştekin \& Öztemiz, 2005: 282). The mental and physical condition affecting the productivity, activity, health, and work quality of employees is occupational stress, and this stress, which exceeds the optimum limit, may decrease the performance of the organization since it creates discomfort in employees (Jha \& Bano, 2012: 88).

The exposure of individuals to excessive stress in the work environment leads to both an increase in costs (an increase in business absences, health expenditures, and insurance expenditures) and a decrease in organizational performance, as well as in job satisfaction, by decreasing the amount of goods and services produced per unit time (Karagül, 2011: 32). According to Sökmen (2005: 6-8), the stress experienced also has consequences that are closely related to the organization, such as the individual's late arrival to work, increase in his/her absenteeism, increase in the labor turnover rate, alienation of the employee to work and workplace, and decrease in his/her performance.

\section{Studies Conducted on the Relationship Between Stress Management and Job Performance in Organizations}

When the literature studies covering the relationship between organizational intelligence and job performance are examined, it is observed that organizational intelligence is mostly evaluated as an independent variable. These studies and the results obtained are summarized in Table 1. 
Table 1: Literature Review

\begin{tabular}{ll}
\hline Study & Data \\
\hline Yılmaz, 2006 & $\begin{array}{l}\text { This study was conducted by applying a questionnaire to 170 } \\
\text { personnel serving at the 40th Infantry Training Regiment } \\
\text { Command in Isparta }\end{array}$ \\
\hline Bashir \& Ramay, 2010 & $\begin{array}{l}\text { This study was conducted to investigate the relationship } \\
\text { between job stress and job performance by applying a } \\
\text { questionnaire to } 144 \text { employees of a bank in Pakistan. }\end{array}$ \\
\hline Örücü et al., 2011 & $\begin{array}{l}\text { This study was carried out to determine the stress levels of } \\
\text { employees working in the education and health sectors and } \\
\text { to examine the effects of stress on performance, and in the } \\
\text { study, a questionnaire was applied to 156 employees in the } \\
\text { education and health sectors in Manyas district of Balikesir } \\
\text { province. }\end{array}$ \\
\hline $\begin{array}{l}\text { This study was conducted to determine factors related to } \\
\text { occupational stress and their relationship with organizational }\end{array}$ \\
performance, with 150 people working in different \\
departments of a private university in Sudan. The results \\
were obtained by applying a questionnaire.
\end{tabular}

\begin{tabular}{ll}
\hline Yozgat et al., 2013 & This study was carried out among 424 public sector \\
& employees in Istanbul to examine the relationship between \\
& job stress and job performance by accepting emotional \\
& intelligence as a moderator variable.
\end{tabular}

Results

- There is a significant relationship between stress level and performance level. A certain level of stress has a positive effect on performance. Excessive stress affects performance negatively.

- Job stress is in a negative relationship with job performance and affects employee performance adversely when stress emerges.

- No relationship was found between the stress level perceived by employees in the work-life and their performance.

Özbağ et al., $2014 \quad$ This study was conducted in order to evaluate the effects of role stress (role conflict and role ambiguity) and organizational barriers on job performance, and the data were collected through providing face-to-face interaction with 195 employees working in four private sector organizations in Turkey.

Gökgöz \& Altuğ, 2014 In this study, a questionnaire was applied to 340 instructors of two state universities in Thrace in order to determine the relationship between organizational stress factors encountered by instructors and their performance.

Türkmen, 2015 This study was conducted to examine the relationship between stress created on health care workers by organizational stress sources and the labor performance by applying face-to-face interviews and questionnaires to 118 hospital employees in Balıkesir.

\begin{tabular}{ll}
\hline Tonbul, 2017 & This study was conducted by applying a questionnaire to 265 \\
officers in Ankara/Yenimahalle Municipality to examine the \\
effects of organizational stress on the performance of \\
employees.
\end{tabular}

Çargan, 2018 This study was conducted by applying a questionnaire to 259 teachers in Kirklareli with the aim of determining the organizational stress factors that teachers were exposed to, and to which extent this affected the labor performance.

\begin{tabular}{ll}
\hline Koca \& Yıldı, 2018 & This study was conducted in order to investigate the \\
& relationship between stress sources, job satisfaction, and job \\
& performance of football referees by applying a questionnaire \\
& to 140 referees in Muğla and Giresun.
\end{tabular}

Ülbeği et al., 2019

Source: Compiled by the author.
In this study, the relationship between manager-induced undermining behavior and employee performance was investigated. Furthermore, information was collected from 367 nurses working in hospitals in Adana through the questionnaire in order to investigate the mediator role of job stress and emotional burnout in this relationship, as well as the serial mediation role.
- The results showed that employees experience high levels of job stress. Job stresses affecting employees are the role conflict and uncertainty, the lack of promotional opportunities and feedback, the lack of participation in decision-making processes, excessive workload, inadequate working conditions, and interpersonal relationships. job stresses negatively affect the general health, job satisfaction, and performance of employees.

- There is a negative relationship between job stress and job performance in the public sector.

- It has a moderate effect on the relationship between emotional intelligence, job stress, and job performance.

- It was observed that role ambiguity was not statistically significant, and that role conflict and organizational barriers had a negative relationship with job performance.

- There is a positive relationship between stress factors and labor performance.

- While inadequate salary and wage imbalance were determined as the most stress creating factors among the stress factors related to the organizational structure and management, the situation when they experience the least stress was determined as not giving information outside their own work.

- As the performance related to job success increases, the stress caused by the organizational structure and management also increases.

- The labor performance of employees decreases if organizational stress factors increase.

- As stress factors originating from the organizational structure and policies increase, job success falls.

- The fact that the participants have little or much professional experience has no positive or negative effect on their stress levels and labor performance levels.

- There is a significant correlation between the stress levels and performance levels of the participants.

- Factors prompting to stress have a significant and negative relationship with the job performance of football referees.

- Job satisfaction has no mediation effect between stress-prompting factors and job performance.

- Job stress has a negative effect on employee performance.

- Job stress plays a mediator role in the effect of social undermining on employee performance.

- Job stress and emotional burnout have a serial mediation effect on the employee performance of social undermining. 
The results of the study demonstrate that the consequences of stress on the physical and mental existence of people affect the working performance adversely in general. Individuals who are exposed to excess stress lose their determination to work and willingness to work. The individual performance is the level of success in tasks that employees have to perform. The organizational performance is the consideration of organizations as a whole, i.e., the degree of success of the whole system. As the stress of individuals increases, their performance decreases. Therefore, organizational performance is also affected by this (Erbaş1 et al., 2012: 101).

Stress experienced and unmanaged in the organization will cause employees to become increasingly nervous, to turn into hard-tolive people, will deteriorate business relations, will make employees take wrong decisions, will reduce their performance, and, thus, increase their absenteeism, personnel turnover rate, and the rate and cost of work accidents (Skeja, 2019: 76). Kılıç et al. (2013: 74) stated that with the increase of stress to the optimum level, health problems would start in employees, there would be a decrease in individual productivity, and occupational accidents would increase with the loss of motivation and the decrease in attention. The authors added that in an organization that could not manage the level of stress, the absenteeism rate, conflicts, and the feeling of burnout syndrome would gradually increase, and organizational activity, productivity, and individual performance would decrease.

Despite the negative consequences created by stress in organizations, Turgut (2016: 21) emphasized that the stress experienced at a certain level in organizations increases motivation and management, provides alertness and vitality, and ensures high energy sensation. Positive features of stress, such as paying attention to details, acting in line with the unity of aim and goal, and enhancing performance, were also emphasized. According to Arıcan (2011: 71), a small amount of stress improves job performance. Stress at a certain level provides employees with opportunities to do their jobs better and find newer and better ways. Constructive stress also enables employees to mobilize their creative power, increase their business success, and feel enthusiasm while performing their duties.

Stress is the essential struggle element for employees who make an effort to maintain their lives and who want to provide satisfaction in their economic, social, and cultural roles. Even improvements to be made in the elements among organizational stress factors, such as general policies, structural disturbances of the business, and the inadequacy of the physical environment, are positive steps for stress management (Biricik, 2018: 61). Since the culture in the organization affects the success of preventing and managing stress, open and insightful communication away from criticism and blame is crucial (Ayaz, 2019: 25).

\section{Conclusions}

Stress is an inevitable part of business life. Business life is also one of the most important sources, causing stress. Especially the working conditions in business life, the order and structure of the workplace environment, organizational climate, relationships between employees, the quality of the work, and harmony between employees determine the level of organizational stress in the business life. Any negative situation on the functioning and implementation of these factors may reduce the performance of employees. Stress that causes social negativities brings about many negative psychosocial results from individuals' dissatisfaction with their job to the decrease in their productivity and performance. Since the psychological structures of employees are reflected in their careers, their being stressful means that the organization is stressful. As any kind of problem caused by stress directly affects the performance of the individual, this situation is also reflected in the employee's business relations and success in the workplace. On the other hand, the individual's qualifications, skills, and ability to cope with stress factors he /she encounters will also increase the effectiveness and performance of the organization to that degree.

When previous studies conducted in various sectors on the subject are examined, employees are observed to experience organizational stress. Organizational stress factors affecting employees are role uncertainty, role conflict, regulatory barriers, organizational structure and policies, much/little professional expertise, insufficient salary, wage imbalance, administrative stress factors, the lack of promotional opportunities and feedback, the lack of participation in decision-making processes, excessive workload, inadequate working conditions, interpersonal relations, and social undermining. The results indicate that these stress factors have a positive and/or negative relationship with the mental and physical health, jobs, and performances of employees.

The high level of organizational stress in businesses may indicate that there are deficiencies in the management and policies of the business and that organizational systematics, and performance of the individual/organization are impaired. The adverse effects of stress will not only affect the employee but will also directly affect his/her performance while doing the job and, therefore, the success of the business. Therefore, businesses should detect the causes of organizational stress, develop their stress prevention methods, and also ensure the participation of employees in practice. In order to increase the levels of stress, productivity, performance, and especially motivation, the administration must contribute to employees both individually and organizationally. In this way, the reducing effect of stress-creating factors on individual and organizational performances in businesses can be prevented or reduced.

\section{References}

Akgündüz, S. (2006). The Effect of Organizational Stressors (Sources of Organizational Stress) On Job Satisfaction And A Research For Bank Employees. Master Thesis, Dokuz Eylül University, Institute of Social Sciences, İzmir.

Altan, S. (2018). The Sources Of Organizational-Related Stress And Major Problems Caused By Organizational Stress. Stratejik Ve Sosyal Araştırmalar Dergisi, 2(3), 137-158. 
Arıcan, K. (2011). The Sources of Organizational Stress: A Conceptual Analysis. Eğitim ve İnsani Bilimler Dergisi: Teori Ve Uygulama, (4), 55-76.

Armağan, E., \& Kubak, S. (2013). A Practice On The Effect Of The Stress Level Of Salespersons' Performance. Organizasyon Ve Yönetim Bilimleri Dergisi, 5(2), 34-50.

Ayaz, N. (2019). Work Stress And Coping With Work Stress: A Study On Tourist Guides. Ph.D. Thesis, İzmir Kâtip Çelebi University, Graduate School Of Social Sciences, İzmir.

Aydın, C., \& Çavuş, S. (2017). Organizational Stress And Burnout Levels of The Hospitality Businesses employees In Kusadasi. Manas Sosyal Araştırmalar Dergisi, 6(5), 79-95.

Aydın, Ş. (2004). Organizational Stress Factors in Hotel Businesses: Application of 4-5 Star Hotel Businesses. Dokuz Eylül Üniversitesi Dergisi, 6(4), 1-21.

Bashir, U., \& Ramay, M. I. (2010). Impact Of Stress On Employees Job Performance: A Study On Banking Sector Of Pakistan. International Journal Of Marketing Studies, 2(1), 122-126.

Baytaş, B. (2018). A Research On The Effects Of Psychological Capital, HRM Applications And HRM Effectiveness Of Line Managers On Work Performance Of Employees. Master Thesis, Başkent University, Institute of Social Sciences, Ankara.

Bilgili, H., \& Tekin, E. (2019). An Investigation Of The Relationships Between Organizational Stress, Organizational Commitment And Learned Resourcefulness. Opus Uluslararası Toplum Araştırmaları Dergisi, 11(18), 2165-2200. https://doi.org/10.26466/opus.557530

Bin, A. S. (2015). The Relationship Between Job Satisfaction, Job Performance And Employee Engagement: An Explorative Study. Issues İn Business Management And Economics, 4(1), 1-8. http://dx.doi.org/10.15739/IBME.16.001

Biricik, Y. S. (2018). An Analysis On Academic Staff's Source Of Organisational Stress And The Level Of Coping With The Stress In Respect Of Learned Resourcefulness. Ph.D. Thesis, Atatürk University, Winter Sports and Institute of Sport Sciences, Erzurum.

Çargan, O. (2018). The Effect Of Stress On Performance Of The Personnel: A Research On Teachers. Master Thesis, Kirklareli University, Institute of Social Sciences, Kirklareli.

Chen, J. C., \& Silverthorne, C. (2008). The Impact Of Locus Of Control On Job Stress, Job Performance And Job Satisfaction In Taiwan. Leadership \& Organization Development Journal, 29(7), 572-582. http://dx.doi.org/10.1108/01437730810906326

Civan, A., Özdemir, İ., Gencer, Y. G., \& Durmaz, M. (2018). Exercise and Stress Hormones. Türkiye Spor Bilimleri Dergisi, 2(1), $1-14$.

Demirer, M. C. (2019). Effects Of Person-Organization On Job Performance: Mediating Role Of Happiness. Atatürk Üniversitesi İktisadi Ve İdari Bilimler Dergisi, 33(1), 283-302.

Düğenci, A. (2018). The Analysis of Relationship Between Stress Coping Methods and Life Satisfaction of Physical Education and Sports Students. Master Thesis, Balıkesir University, Health Sciences Institute, Balıkesir.

El Shikieri, A. B., \& Musa, H. A. (2012). Factors Associated With Occupational Stress And Their Effects On Organizational Performance In A Sudanese University. Creative Education, 3(01), 134-144.

Erbaş1, A., Ünüvar, O., \& Arat, T. (2012). Determination Of Satisfaction Levels And Organisational Stress Factors Affecting The Bank Employees' Performance. Verimlilik Dergisi, 3, 97- 114.

Ergül, A. (2012). How Stress in Working Life Effects İndividual Performance: A Research İntended for Education and Health Employees. Master Thesis, Balıkesir University, Institute of Social Sciences, Balıkesir.

Gökgöz, H., \& Altuğ, N. (2014). A Research Into The Effect of Organizational Stress On The Performance of Teaching Staffs. Ege Academic Review, 14(4), 519-530.

Gümüştekin, G. E., \& Gültekin, F. (2009). Effects Of Sources Of Stress On The Career Management. Dumlupınar University Journal Of Social Sciences, 23, 147-158.

Gümüştekin, G. E., \& Öztemiz, A. B. (2005). Productivity And Performance Interaction With Stress Of Organizations. Çukurova Üniversitesi Sosyal Bilimler Enstitüsü Dergisi, 14(1), 271-288.

http://dx.doi.org/10.17860/mersinefd.401087

Işık, E. (2007). A Research Between Mobbing Treatment And Job Stress Relationship In Workplace. Master Thesis, Yıldız Teknik University, Institute of Social Sciences, İstanbul.

Jha, R. K., \& Bano, B. (2012). Impact Of Locus Of Control On Job Stress: An Empirical Study. International Journal Of Decision Making In Supply Chain And Logistics, 3(1), 87-95.

Karagül, M. (2011). Organizational Stress And Stress Management: The Case Of Malatya Court House. Master Thesis, Balıkesir University, Institute of Social Sciences, Balıkesir.

Keskin, E., \& Gündoğan, H. (2019). The Relationship Between Five-Factor Personality Traits And Job Performance: A Case Study On Five-Star Hotels. Journal Of International Social Research, 12(62), 1465-1478. http://dx.doi.org/10.17719/jisr.2019.3155

Kılıç, R., Yumuşak, S., \& Yıldız, H. (2013). A Research On Relationshipbetween Sources Of Individual And Organizational Stress For Bank Personnel. Eskişehir Osmangazi Üniversitesi İktisadi Ve İdari Bilimler Dergisi, 8(2), 71-92.

Koca, S., \& Yıldız, S. M. (2018). An Investigation Of Relationships Among Stress Resources Of Football Referees, Job Satisfaction And Job Performance. Spor Bilimleri Araştırmaları Dergisi, 3(2), 195-207. https://doi.org/10.25307/jssr.334624 
Meydan, C. H., Dirik, D., \& Eryılmaz, İ. (2018). The Moderating Role of Pelz Effect In The Relationship Between Leader Power Sources and Job Satisfaction. Yönetim Ve Ekonomi: Celal Bayar Üniversitesi İktisadi Ve İdari Bilimler Fakültesi Dergisi, 25(1), 75-92.

Mirela, B., \& Mădălina-Adriana, C. (2011). Organizational Stress And İts Impact On Work Performance. Conference Proceedings, European Integration - New Challenges. 1622-1628.

Nart, S., \& Batur, O. (2014). The Relation Between Work-Family Conflict, Job Stress, Organizational Commitment And Job Performance: A Study On Turkish Primary Teachers. European Journal Of Research On Education, 2(2), $72-81$. https://doi.org/10.15527/ejre.201426250

Örücü, E., Kılıç, R., \& Ergül, A. (2011). The Effects Of Stress On Individual Performance In Business Life: A Research For Education And Healthcare Staff. Akademik Bakış Dergisi, 26, 1-21.

Özbağ, G. K., Çekmecelioğlu, H. G., \& Ceyhun, G. Ç. (2014). Exploring The Effects Of Perceived Organizational Impediments And Role Stress On Job Performance. Procedia-Social And Behavioral Sciences, 150, 1129-1136.

Özen, H. Ö. (2013). According To The Genger Employees Organizational Stress Levels Of Exposure: A Study On Employees Parliament Press And Public Relations Directorate. Uludağ Üniversitesi İktisadi Ve İdari Bilimler Fakültesi Dergisi, . Xxxı1, No. 1, 97-115.

Skeja, A. (2019). The Role Of Stress On The Relation Between Cyberloafing And Creativity: The Case Of Kosova. Ph.D. Thesis, Trakya University, Institute of Social Sciences, Edirne.

Sökmen, A. (2005). The Role Of Gender In Determining The Causes Of Stress: An Empirical Research In Adana. Ekonomik Ve Sosyal Araştırmalar Dergisi, 1: 1-27.

Tekin, B., \& Deniz, B. (2019). Is Locus Of Control An Effective Factor On Job Stress, Job Performance And Job Satisfaction Levels Of Accounting Professionals? Muhasebe Ve Finansman Dergisi, (84), 65-94. https://doi.org/10.25095/mufad.625730

Tekin, G. O. (2010). Stressors In The Work-Life And Effects On Staff In Public Institutions: The Case Of Edirne. Master Thesis, Trakya University, Institute of Social Sciences, Edirne.

Tekiner, M. A., \& Tavas, B. (2016). Employee Job Satisfaction On The Effect Of Stress Management Skills Gain: Sample Of Police Organization. Journal Of International Social Research, 9(42), 1658-1671.

Tonbul, İ. (2017). The Effect Of Organizational Stress On Employees' Efficiency: An Application In Local Governments. Master Thesis, Ardahan University, Institute of Social Sciences, Ardahan.

Turgut, E. (2016). Investigation Of Secondary Education Studying Karateka Of Stress Coping. Master Thesis, Bartın University, Institute Of Educational Sciences, Bartın.

Türkmen, A. (2015). Research Of Organizational Stress Effects On Labour Performance At Medical Establishments (Sample Of Bandırma State Hospital). Master Thesis, Okan University, Health Sciences Institute, İstanbul.

Ülbeği, İ. D., İplik, E., \& Yalçın, A. (2019). The Role Of Job Stress And Emotional Exhaustion In The Relationship Between Social Undermining And Employee Performance. Selçuk Üniversitesi Sosyal Bilimler Enstitüsü Dergisi, (41), 1-15.

Wang, X., Duan, H., Kan, Y., Wang, B., Qi, S., \& Hu, W. (2019). The Creative Thinking Cognitive Process Influenced By Acute Stress In Humans: An Electroencephalography Study. The International Journal on the Biology of Stress, 22(4), $472-481$. https://doi.org/10.1080/10253890.2019.1604665

Yao, B. C., Meng, L. B., Hao, M. L., Zhang, Y. M., Gong, T., \& Guo, Z. G. (2019). Chronic Stress: A Critical Risk Factor For Atherosclerosis. Journal Of International Medical Research, 47(4), 1429-1440. https://doi.org/10.1177/0300060519826820

Yardibi, N. (2018). The Impact Of Teacher Satisfaction Levels From Managers On Business Performance. Mersin Üniversitesi Eğitim Fakültesi Dergisi, 14(1), 426-435.

Y1lmaz, O. (2006). Impact Of Stress On Performance A Study On 40th. Infantry Regiment Leader Personnel. Master Thesis, Süleyman Demirel University, Institute of Social Sciences, Isparta.

Yozgat, U., Yurtkoru, S., \& Bilginoğlu, E. (2013). Job Stress And Job Performance Among Employees In Public Sector In Istanbul: Examining The Moderating Role Of Emotional İntelligence. Procedia-Social And Behavioral Sciences, 75, 518-524. https://doi.org/10.1016/j.sbspro.2013.04.056 